\title{
Theory of Conservatism and Value Relevance of Accounting Information
}

\section{Felix UO ${ }^{1 *}$ and Rebecca Ul ${ }^{2}$}

${ }^{1}$ Department Banking and Finance, Faculty of Management Sciences, University of Benin, Benin City, Nigeria

${ }^{2}$ Department of Accountancy, Faculty of Management Sciences, University of Benin, Benin City, Nigeria

\begin{abstract}
This paper is centered on theory of conservatism and value relevance of accounting information in the Nigeria stock ex-change (NSE) and other related literatures. It reviews the relevance of conservatism and value relevance of accounting information and their comparisons. While there have been a number of studies on this topic in the developed countries not much has been explored in Nigeria. Value relevance has been criticized by extant literature and also that conservatism in accounting as one reason for the observed decrease in value relevance. One of such recommendation was that the financial reporting council and other allied bodies should ensure clarity and provide rules with probably less discretionary tendencies for management to manipulate. The overall aim is to improve credibility of financial information. In order to ascertain the impact of conservatism on value relevance of accounting information, secondary source of data collection, statistical instruments like regression and correlation were used in the analysis of data collected. It was discovered among others that there is the existence of a significant inverse relationship between Market-based conservatism (BMCONA) and Earnings per share (EPS) used as a proxy for stock returns for the pooled OLS, fixed and random effects model. The results suggest that higher conservative practices by companies will affect the informativeness of financial estimates and declines in stock returns may be seen as an outcome of the markets assessment of disclosure credibility. In concluding this study, some recommendations were made. One of such recommendation was that the financial reporting council and other allied bodies should ensure clarity and provide rules with probably less discretionary tendencies for management to manipulate. The overall aim is to improve credibility of financial information.
\end{abstract}

Keywords: Average annual accrual determine stock returns; Book value influence stock returns; Non-operating accruals affect stock returns

\section{Introduction}

The most important source of externally feasible information on companies is the financial statement. Despite it widespread use and continuing advance, the concern has been that accounting practice has not kept pace with rapid economic and high technology changes which invariably affect the value relevance of accounting information. The international accounting standard board for the preparation and presentation of financial statement (IASB Framework) says in paragraph 26 that information is relevant "when it influences the economic decisions of users by helping them evaluate past, present or future events or confirming, or correcting, their past evaluations". Financial accounting standard board concepts statement No. 2, Qualitative characteristics of Accounting information says in paragraph 47 that, to be relevant, "accounting information must be capable of making a difference in a decision by helping users to form predictions about the outcomes of past, present, and future events or to confirm or correct expectations," and goes on to define event and outcome. Conservatism has been one of the obvious characteristics of financial reporting which have been combined with theory and practice of accounting for long time. According to Watt's view [1], conservatism has been considered as an outstanding and dominant feature in accounting and financial reporting (statements) forum since early twentieth century.

The importance of Conservatism is that managers have considerable discretion in measuring firms' economic events, as allowed within those accounting regulation. Accordingly, accounting policy of a firm in reporting its financial performance is one of the governance mechanisms that enable privately informed and self-interested managers to credibly communicate their private, value-relevant information to market investors. Therefore conservatism can provide value relevant information that has not yet been captured in bottomline numbers $[2,3]$ it is required that in the management of liquid assets, an organizational policy must be conservative or aggressive. A conservative policy means lower return and risk while an aggressive policy products higher return and risk. But the two important aims are profitability and solvency.

In their works, Kothari, Haley and Palepu, Verrechia [4] have extensively reviewed studies examining the relation between accounting information and security prices. These studies concluded that financial reports provide new and relevant information to investors although the relevant has considerably come down. Brown et al. found that the relation between stock returns, earnings and book values have deteriorated over time. Collins et al., Francis and Schipper, Ely and Waymire [5,6] examine the relation between returns, earnings and book values they conclude that the relation between returns and earnings has deteriorated, but that this has been offset by an increase in the value relevance of book values. Most of these studies are inconclusive about value of relevance and report that results also depends on variables such as firm characteristics, and country - specific institutions and is also subject to alternative interpretations. Dontoh et al., [7] suggested that the decline in value relevance is more caused by noise in the stock market rather than accounting numbers. Ball and Shivakumar [8] examined the new information content to the investor using quarterly earnings announcement. They find that quarterly

*Corresponding author: Umanhonlen Ogbeiyulu Felix, Department Banking and Finance, Faculty of Management Sciences, University of Benin, Benin City, Nigeria, Tel: 08035035671; E-mail: ogbeiyulu4real@yahoo.com

Received December 22, 2014; Accepted January 10, 2015; Published January 17,2015

Citation: Felix UO, Rebecca UI (2015) Theory of Conservatism and Value Relevance of Accounting Information. J Account Mark 4: 121. doi: 10.4172/21689601.1000121

Copyright: ( 2015 Felix UO, et al. This is an open-access article distributed under the terms of the Creative Commons Attribution License, which permits unrestricted use, distribution, and reproduction in any medium, provided the original author and source are credited. 
results constituted a mere $1 \%-2 \%$ of the total annual information, which provided only a "modest" amount of incremental information to the market. Hung [9] examined the value relevance of the financial statements in the international context and found that shareholder protection improved the effectiveness of accrual accounting. Ali and Hwang [10] examined the value relevance of accounting information to five country level factors such as bank oriented financial systems, continental Vs British - American model, tax rules and audit spending. Would moving to International Financial Reporting Standards (IFRS) improve the relevance of financial statements? Chen et al., [11] empirically examined the data between 1991 and 1998 and found that accounting information was value relevant despite the market being relatively young and with in-adequate reporting at that time.

Accordingly, Heibatollah and Zou compare the value relevance of accounting information in different segments of the Chinese stock market which used Chinese General Accepted Accounting Principle (GAAP) and International Accounting Standards (IAS). They found out that the accounts prepared using international GAAP was more value relevant than that of Chinese GAAP. Brimble and Hodgson [12] examined the value relevance of accounting statements in the Australian context. After controlling for market inefficiencies and nonlinearity, they found out that the value relevance of the conventional core accounting earnings had not declined in the last twenty-eight years.

\section{Theoretical Framework}

Watts argues that conservatism in financial reporting arises for a number of economic reasons. In particular, conservatism was generated by:

1. It role as part of efficient technologies employed in firm governance (e.g. management compensation) and firm contracts with external parties (e.g. debt contracts).

2. Increases in litigation cost.

3. Regulators' asymmetric loss functions.

4. Links between reported income and income taxes.

The common attribute in these economic determinants is that there is an asymmetric loss function involved. For example, shareholders have an asymmetric loss function due to their limited liability and so have incentives to transfer wealth from debt holders by overstating earning and net assets. Similarly, managers have limited liability and have incentives to overstate financial performance and transfer wealth from shareholders. Litigation costs are asymmetric. Managers, auditors are likely to be sued for overstatements of earning and net assets than for understatements. The choice of accounting method is not limited to the factors that influence the company cash flow, but also earning as an indicator of company's value. This is commonly called as an economic consequence.

An accounting number is termed "value relevant" if it is significantly related to dependent variable. Theoretically value relevance has a combination of a valuation theory in addition with contextual accounting argument that allows predictability of how accounting variables relate to the market value of equity. Furthermore, contextual accounting arguments of value relevance would typically predict the relation between accounting variables and market value. Value relevance gives evidence as to whether the accounting numbers relate to value in the predicted manner. To the extent value relevance captures information reliability and latter increases earnings precisions, greater value relevance will reduce information risk.

The Feltham Ohlson model could show the value relevant concept in terms of conservatism. This model reveals that conservatism is an appropriate concept as it shows the company growth because the net asset is reported lower than market value. Penman and Zhang also stated that conservatism is aligned with growth. That is, conservative accounting would reduce earning, when there is net asset growth hence result to a lower accounting rate of return. Lev and Nissim [13] use the magnitude of expenses as reported for financial reporting Vs tax reporting as a measure of downward bias in earning in a given period.

If a change in a reported accounting of return that is induced by a change in investment is temporary, quality of earnings issues arise. If an analyst accepts the current book rate of return as an indicator of future rates of return, they will be misled if the reported rate of return is temporarily affected by the joint effect of conservative accounting and investment activity. But if the analyst penetrates the joint effect, they will discover the reported number to be poor quality of long run "sustainable" profitability. The lower reported earning creates a hidden reserve, so it will boost the higher earnings in the future periods.

Based on clean surplus theory, Ohlson shows that market value could be shown in the income statement and balance sheet. This reveals a consistent conceptual of measurement.

\section{Conservatism Accounting}

Penman and Zhang consider accounting conservatism as selection of method and estimation from accounting which evidently shows assets book value lower than usual. Thus during inflation conditions choosing of Last-In-First-Out (LIFO) technique instead of FirstIn-First-Out (FIFO) is a conservative method to identify inventory. Similarly, application of least cost in market or (LCM) for allocating the given cost of Research and Development ( $\mathrm{R}$ and $\mathrm{D}$ ) expenditures, selection of depletion fast techniques and policies that lead to consider higher reserve for Bad Debts and recognition of the related accruals for guarantee, are conservative techniques which cause showing book net value of an economic unit lower than real value.

Watt defines Accounting Conservatism as follows: It denotes necessity of attaching difference in demonstrating possibility of recognizing profit versus loss. According to the present definition of conservatism, prediction of future profits should be able to be proved more than future losses. One of the important products of accounting system is financial reports. One of accounting items which are provided and given about financial reports is net profit which has various applications. Calculation of net value for an economic entity is affected by accounting methods and estimations, so there is a possibility for management to manipulate the given profit. Since profit is considered as one of the important criteria for performance evaluation and determinant factor to identify value of economic incorporations, the subject of earnings quality was raised that managers are always responsible for selection and implementation of estimation and basic applied judgments like accounting principles.

\section{Conservatism and Earnings Quality}

Recent financial scandals all over the world, from Enron and World com to parliament in Europe has led to pointing fingers of accusation toward financial reporting. Financial statement and on top of them profit and loss statement is focused by investors. Recently, the subject of quality of reported profit has drawn attention of many researchers. One aspect earnings quality is conservatism, that is, the higher profit is obtained by conservatism, the higher quality it has. The concept 
of conservatism has a long history in accounting. Irrespective of the fact that many accountants agreed on the existence of conservatism for drawing up financial statement, there has been no comprehensive and all-inclusive definition has been presented about it. Nevertheless, two main features of conservatism have been examined in accounting texts: first, descending support of capital book value to its market value; and the second is to tending toward acceleration in identifying of costs and delayed recognition of revenues. Paragraph 95 of Financial Accounting Standard Board (FASB), conservatism is also described as follows: "If there are two estimations of the same receivable or payable fund in the future while incidence probability of both is identical, then conservatism dictates using of the estimation which is less optimistic".

According to the view of financial statement makers, conservatism is considered as an effort to select a certain methods from accounting accepted techniques that result in the following outcomes:

- Slower recognition of sales revenue;

- Faster recognition of cost;

- Evaluation of assets less than real values, and or;

- Evaluation of liabilities greater than real values.

The effects of Conservatism can be attributed to two items: first, is financial reporting standards which require conservative reporting and second is the selected accounting procedures by management to provide financial statements. Often, the conservatism image is given as the second aspect in related literature. Conservatism principle sometimes viewed as an advantage to compensate for some of managements' optimistic views and its tendency toward exaggeration in financial statements which have become evident during twentieth century. Conservatism leaves the subject of resultant profits from maintenance since many accountants believed that by determination of the interested evaluation alternatives, users of financial accounting information will be probably misled. In recent years, the impact of the given concept has been reduced due to a pressure for revealing of more relevant and more reliable information. Theory of earnings quality was purposed for the first time by financial analyzers and Bourse brokers, since they felt that the reported profit might not indicate power of profit to the extent that it is embodied in mind. They found that prediction of future profits based on the reported results is a difficult task. Moreover, Analysers understood that because of several weak points in measurement of accounting information, analysis and synthesis of corporative financial statement is a complex duty.

The basic question is that why analysers are not using the reported net profit and or corporative equity (without equalization) in their assessment and observe precaution. Answer is in that one should pay attention not only to profit quantity in determination corporative value, but also to its quality. Earnings quality means a potential ground for growth of profit and probability of realization of future profits. In other words, value of a given equity does not depend only on equity of each share of the corporation in current year, but it is subjected to corporative future expectancy and profitability power for the next years and coefficient of certainty to it. Earnings quality is to express the reported profit honestly. One of the items which may effect on earnings quality is the method of presenting information about profit. That is the more relevant and reliable profit information is the higher quality the given profit has. Researchers and accounting professional practitioners deems the importance of profit as one of the significant criteria of performance assessment and determinant factor for corporative value so it requires assessing the reported profits by the commercial units.
To evaluate this profit, one concept is used which is called earnings quality. Some of financial analysers, who deem earnings quality as a normal, continuous, repeatable profit and creator of resultant cash flow from an operation, argued that earnings quality is a figure that lies between reported net profit and the resulting cash flow from operation minus non-iterative figures. By a briefly view on enterprise main goal (increase in stockholders' wealth), it is characterized that study on effect of conservative accounting on profit qualitative properties is very important so that it tries to achieve to the given objective by determination of effect of conservative accounting on each of profit qualitative characteristics.

\section{Measuring Conservatism}

Researchers use three types of measures to assess conservatism:

- Net asset measures,

- Earnings and accrual measures, and

- Earnings/stock returns relation measures.

All measures rely on the effect of conservatism's asymmetric recognition of gains and losses on reported accounting numbers, in particular net assets, earnings and accrual.

\section{Net asset measures}

The market value of the assets and liabilities consist of net assets change every period but all these changes are not recorded in the accounts and the financial reports. In conservatism, increases in asset values (gains) that are not verifiable are not recorded while decreases of similar verifiability are recorded. The result is that net assets are understated-are below market value. Researchers obtain estimates of this understatement using models of the valuation of the firm's shares and/or the ratio of the firm's book value of net assets to its equity value (book-to-market ratio).

Valuation model measures: Feltham-Ohlson valuation models [14] are usually employed to estimate the extent of undervaluation of net assets. These models include parameters that reflect the degree of understatement of operating assets. The models induce the understatement by assuming accounting depreciation exceeds economic depreciation. Conservatism parameter estimates are obtained from estimation of the valuation model and from time series estimation of the relation between accounting variables that are inputs to the valuation model.

The valuation model estimate comes from cross-sectional regressions of firm market value on abnormal earnings, assets and investment. A valuation estimation example is Ahmed, Morton and Schaefer [15] who regress firms' goodwill on abnormal earnings, lagged operating assets and contemporaneous investment in operating assets. To the extent the book value of net assets is understated, goodwill is overstated. The coefficient of lagged operating assets should be positive if conservatism has understated the lagged assets.

A time-series conservatism parameter estimate is obtained from the time series regression of abnormal earnings on lagged abnormal earnings and lagged book value of operating assets. Again, the coefficient of lagged operating assets should be positive when conservatism exists. To understand these predictions, note that the more excess depreciation understates the operating assets. Again, the coefficient of lagged operating assets should be positive when conservatism exists. To understand these predictions, note that the more excess depreciation understates the operating assets, the greater is the coefficient applied 
to the lagged operating assets to explain either goodwill or abnormal earnings.

Book to market measures: Beaver and Ryan [16] measure conservatism using firm's book-to-market ratios based on the notion that, ceteris paribus, firms using conservative accounting report lower net assets and lower book-to-market ratios. Using pooled time series and cross sectional data they regress book-to-market ratios on individual year and firm dummy variables and on individual firm stock returns for the current and previous five years. The estimated coefficient of an individual firm's dummy captures the persistent portion of the difference between the firm's book and market values of equity. The lower the coefficient, labelled the "bias component", the more book value of net assets is biased downward and the more conservative the firm's accounting. By construction, because the mean coefficient is zero, the coefficient estimates relative conservatism and not aggregate conservatism. This book-to-market measure is used to proxy for the extent to which conservation varies across firms.

\section{Earnings and accrual measures}

Conservatism means that gains tend to be more persistent than losses. Unverifiable increases in asset values (gains) are not recognized at the time they occur but over future periods as the cash flows generating those increases are realized.

Losses of the same degree of verifiability as the unverifiable gains is recognized as they occur rather than in the future as the cash flow decreases are realized - there is a lump sum drop in earnings at the time of the loss rather than a flow of reduced earnings in the future. Firms whose earnings are negative are more likely to have recognized losses. Since, on average, the losses do not recur in future periods, negative earnings and earnings decrease are less likely to persist than positive earnings and earnings increases. Those negative earnings and earnings decreases are transitory. The persistence of earnings and earnings changes provides measures of conservatism.

Conservatism's asymmetrical treatment of gains and losses produces an asymmetry in accruals. Losses tend to be fully accrued while gains do not. This causes accruals to tend to be negative and cumulated accruals to be understated. As a result negative periodic net accruals and negative cumulative accruals (cumulated over periods) are used as measures of conservatism. In addition, conservatism suggests losses, with their capitalization of future flows, produced large accrual than to gains. This predicts negatively skewed distributions of accruals and earnings and suggests estimates of the negative skewness of distributions of earnings, earnings changes and accruals as a measure of conservatism.

Earnings measures: Literatures have it that negative earnings changes are more likely to reverse in the next period than positive earnings changes. In confirming this result, Basu regresses earnings changes, deflated by beginning-of-period price, on lagged deflated earnings changes for samples of positive and negative earnings changes. The estimated lagged earnings coefficient for positive earnings changes is insignificantly different from zero, consistent with positive earnings coefficient for negative earnings changes is significantly negative, but is not significantly different from minus one, the value expected when negative earnings changes are completely transitory. This result is consistent with write-offs due to conservatism causing negative earnings changes. When those write-offs capture all expected future losses on the assets, they are completely transitory.

Accrual measures: Givolyn and Hayn [17] noted that conservatism reduces cumulative reported earnings over time. They suggest the sign and magnitude of accumulated accruals over time are measures of conservatism. For firms in a steady state with no growth and neutral accounting, earnings converge to cash flows and periodic accruals converge to zero. "A consistent predominance of negative accruals across firms over a long period is ceteris paribus; an indication of conservatism, while the rate of accumulation of negative accruals is an indication of the shift in the degree of conservatism over time".

Consistent with conservatism, Givoly and Hayn discovered that the distribution of return on assets, whether derived from time-series of individual firms or the cross-section of firm-years, is negatively skewed for most of the period they examine. They also discovered that over the period accruals, other than depreciation, cumulate to a negative amount equal to $16 \%$ of cumulative earnings over the same period. This accumulation is consistent with the timing of a large increase in conservatism observed in the time-series evidence on the earning / stock return relation.

\section{Earnings stock returns relation measures}

Stock market prices tend to show asset value changes at the time those changes occur whether those changes imply losses or gain in asset value-stock returns tend to be timely. Since conservatism predicts that accounting losses are recorded on a timely basis but gains are not, accounting losses are predicted to more contemporaneous with stock returns than are accounting gains. Basu predicts that stock returns and earnings tend to reflect losses in the same period, but stock returns reflect gains earlier than earnings. To provide estimates of his conservatism measure Basu regresses annual earnings on stock returns of the same year. He predicts a higher coefficient of stock returns than for a sample of firms with positive returns. Using USA data, Basu discovered results consistent with his predictions. Using variations on this methodology, many other studies replicate the result, including Ball et al. and Holthausen and Watts.

What is Value?: Firm value is defined as the total value of a company's stock and accounting figures are value relevant if they can capture information that affects the value of a company's stock. However, firms and other assets are valued differently depending on the context. Runsten defines three value concepts: economic value, market value, and accounting value. Economic value refers to the notion that the value of any asset equals the future cash flows that can be gained from the asset. This value concept is consistent with the discounted cash flow model, which states that the value of an asset equals all future cash flows discounted to present value. Market value is the value of a firm on the stock market and is based on trade and investors consensus beliefs about firm value [18].

According to Runsten, information is often assumed to be the basis on which investors' beliefs and expectations about market value are formed. He argues that observed stock prices could be viewed as a measure of the market's valuation of the claim on companies' future value creation. He concludes that stock prices thus serve as indicators of the market's expectations of the future success of the firm. Accounting value refers to the book value of equity found in the balance sheet While information is often assumed to be the basis on which investors' beliefs and expectations about market value are formed. Accounting value is the result of a measurement procedure that corresponds to accounting regulations and law. Accounting generates a description of the firm in an attempt to measure and describe its financial position and performance. According to Runsten, a close correspondence between equity book value and market value can be achieved if accounting 
information conveys a good description of the firm's value. He argued that all three value concepts could even coincide, provided a strong set of assumptions. In practice, however, this is not very realistic. Rather than separate systems generating identical descriptions, one type of description may in practice facilitate the functioning of another. "The output of the accounting procedure may for example, be used as input in the pricing procedure". The various concepts of value have implications for accounting, which objective it is to provide information about the financial position and performance of companies, as well as for the value relevance of accounting information. If accounting provides a poor description of the firm, the value relevance of such information will likely be low.

\section{Accounting Regulations and Value Relevance}

According to beaver [19], value relevance research requires an indepth knowledge of accounting institutions and accounting standards. $\mathrm{He}$ argues that differences in accounting regulations between countries favour research based on case country studies rather than comparative studies where the researcher has limited possibilities to understand the accounting institutions and standards of all countries researched. According to Marton, there are significant differences in the value relevance of harmonized and non-harmonized accounting. He argued that choices on content affect the value relevance of accounting information.

Gjerde et al. [20] investigated the value relevance of financial reporting in Norway between 1965 and 2004 to discover if the work of accounting legislators and standard setters has increased the value relevance of such reports. Their main findings are that the overall value relevance attributed to accounting quality has increased significantly over the period, which according to Gjerde et al., suggests that public regulatory efforts have been successful at achieving more relevant financial reporting over time. They especially pointed out the positive effect on value relevance of the Accounting Act 1998 as the overall value relevance increased in the period 1999 to 2004 after this law was enacted.

\section{Usefulness of value relevance research to standard setters}

Provided the relation between value relevance and accounting regulations, it has been debated whether value relevance research is useful to standard setters discuss five issues that limit the usefulness of value relevance research to standard setters. These are:

1. That standard setter cannot possibly meet the information requirements of all users of accounting information; favouring investors would necessitate limiting the usefulness for other groups of users.

2. The value relevance literature has not provided very strong results in terms of the strength of the association between stock returns and accounting information (particularly earnings),

3. The results generated by value relevance studies are inevitably influenced by externalities that weaken the inferences that can be drawn from such studies.

4. Concerns can be raised as to the relative sophistication of market participants, particularly as to whether the complex statistical association models employed in value relevance studies can be interpreted by investors.

5. Standard setters require conclusive results and emphasize questions that comprehensively deal with an issue, which is not the case in value relevance studies since they are often incremental in nature.

Barth et al. refuted the concerns raised about the usefulness of value relevance research to standard setters. They argue that:

i. The value relevance literature does provide insights useful to standard setters because it is based on well-accepted valuation models.

ii. Investors are the main users of accounting information focusing on this group of users are thus relevant and useful.

iii. Despite simplifying assumptions, empirical valuation models can be used in a value relevance research design.

iv. Conservatism can be dealt with by means of research design.

v. Value relevance research is not designed to test the usefulness of accounting amounts.

vi. Common econometric issues in research design can be, and are, mitigated by applying various statistical techniques.

\section{Accounting regulation and declining value relevance}

Several researchers are of the opinion that deficiencies in accounting regulation have caused the value relevance of accounting information to decline. For example, Rimerman argues that one of the reasons for the declining value relevance of accounting information is that the current business environment is significantly different from the one that existed when Generally Accepted Accounting principles (GAAP) were developed.

Researchers have also discussed the increasing need for more relevant and timely accounting information due to the increased sophistication of investors. According to the researchers, an increased focus on this issue would perhaps reduce investors' reliance on nonaccounting sources of information.

\section{Perspective on value relevance}

There are different ways of interpreting value relevance. Francis and Schipper have identified four different approaches to studying the value relevance of accounting information. They are the fundamental analysis view, the prediction view, the information view, and the measurement view of value relevance. According to Nilsson, the various studies differ, among other ways, in the perspective on accounting (measurement versus information), market assumption (efficient versus inefficient), and research methods applied.

\section{The fundamental analysis view of value relevance}

The fundamental analysis approach to value relevance focuses on the usefulness of accounting information in equity valuation. Financial statement information is assumed to be relevant for valuation if portfolios based on this information are associated with abnormal returns. Thus, it is not assumed that the market is at all times efficient but that there is the possibility of earning abnormal returns simply by using accounting information. The value relevance is examined by measuring returns generated by implementing trading strategies based on accounting information.

As encapsulated in Nilsson, several studies have adopted the fundamental analysis view of value relevance. Chan et al., dealt with investment strategies based on historic accounting earnings growth; Sloan, also examined trading strategies that imply a long position in firms with relatively less accruals and selling short firms with relative 
more accruals in their accounting earnings, Lakonishok et al. did studied on investments in firms with low ratios of market value to accounting fundamentals. Nilsson concludes that "most of these studies indicated that accounting information is useful in predicting future returns.

\section{The prediction view of value relevance}

This interpretation of value relevance is also related to fundamental analysis research. Accounting information is assumed to be value relevant if it can be used to predict future earnings, dividends, or future cash flows. Most researchers adopting this view of value relevance have studied the usefulness of accounting information for earnings prediction.

Another study that adopts the prediction view of value relevance is the study by Skogsvik, who examined whether one could accurately predict future return on equity (ROE) by the means of information contained in a large number of financial ratios and Skogsvik implemented trading strategies based on these predictions.

\section{The information view of value relevance}

Accounting figures are assumed to have information content if the release of new information modifies investors' beliefs about future cash flows and thus causes price revisions. Information content studies use statistical association models to examine how the stock market reacts to the disclosure of new accounting information. Hence, returns are the natural market metric in such studies.

Together, Ball and brown, beaver were the originators of empirical association studies using statistical models in the field of value relevance of accounting information [21]. The motivation for their work was the assertion that accounting information, as a measure of company performance, should be reflected in stock prices and thus useful for investors. Their conclusion was that financial statements must have some worth to shareholders since they cost money to produce.

According to Nilsson, the work of Ball, Brown and Beaver led to the large body of literature that examines the value relevance of accounting information. He argued that numerous researchers have used the research methodology established by these pioneers in studying the market reaction to announcements of accounting information. $\mathrm{He}$ stated that the majority of these studies examine the relationship between the earnings measure and its components and stock prices. Several studies have investigated the market re action to other accounting figures and adjusted measures of earnings. One example is Booth et al., who suggest that earnings in Finland might be strongly manipulated by management. They therefore used various adjusted earnings measures in order to mitigate the manipulated earnings measure.

\section{The measurement view of value relevance}

Under the measurement of value relevance, accounting information is value relevant if it captures or summarizes information that in turn affects stock prices. Nilsson stated that "If an accounting item has a reliable association with a market metric, then the accounting metric captures or aggregate the information that is used by market participants to determine prices or returns". This is the definition of value relevance under the measurement view.

According to Nilsson, both price and returns can be used as market metrics under the measurement approach, unlike in information content studies. He argued that researchers that use price as the market metric study the validity of accounting information as summary measures of the events that have affected firms up to a specific date. Return-based studies, on the other hand, study the ability of accounting information to capture events that have affected the firm over the return interval. Another difference between the information view and the measurement view of value relevance is that the timeliness of new information is less important. The information view does not presume that investors actually use accounting information in their valuations; it is good enough if it summarizes the information and events that have affected stock prices during the return period. Hence, accounting information does not have to be decision relevant if more timely information exists. The last distinction between information content studies and the measurement view of value relevance is the research methods applied. Nilsson stated that: "information content studies often adopt an even-study method, while regression analysis is the bread and butter of value relevance research from the measurement perspective".

Most recent value relevance studies focused on the measurement view of value relevance. According to Nilsson, many of these studies have examined the value relevance of earnings, equity book values or combinations of the two. He mentioned Easton and Harris [22] for an early US example, Easton et al. extend that study by aggregating earnings and returns over periods up to ten years. Their results suggested that a ten-year return period is capable of significantly explaining stock returns.

\section{Value relevance and the efficient market hypothesis}

The efficient markets hypothesis states that it is impossible to "beat the market" because stock market efficiency causes existing share prices to always incorporate and reflect all relevant information [23].

According to Holthansen and Watts, most value relevance studies assume market efficiency. However, value relevance research under the measurement view does not require this assumption. The only assumption required is that market value reflects investor's beliefs and estimates. Although most value relevance studies adopt the measurement view nowadays, the efficient markets hypothesis has implications for any value relevance study adopting an event-study approach, which is the normal method of information content studies. According to Nilsson, market efficiency is crucial for information content studies, which presume that investors actually use accounting information for making decisions. He argues that inefficient markets would cause such studies to suffer in reliability since they depend on the assumption that investors immediately reaction to new information and use it to revise stock prices. This is apparent with regards to the small return, windows often used in information content studies, usually the days or weeks around the announcement date.

Moreover, according to Barth et al., the efficient markets assumption is important when testing estimated coefficients on accounting variables to see if they differ from theoretical benchmark, value derived from theoretical valuation models. Nevertheless, the evidence against market efficiency is mounting. In information content studies, this problem reveals itself in what is sometimes called post-announcement drift, that is price revisions associated with new information disclosed after the announcement date and outside the return window. Attempts to get around this problem include extending the return window in order to allow the market to catch up. In defence of the value relevance literature, Barth argued that there is significant evidence suggesting that markets are reasonably efficient at processing publicly available information. They also point out that markets does 
not have to be totally efficient since stock prices reflect the consensus beliefs of investors and therefore serve as a common proxy for value. Market efficiency is not a requirement for this study since the research approach adopts the measurement view of value relevance.

\section{Conceptual Framework}

The conceptual framework defines conservatism as a means to assure reliability in accounting information, as "a prudent reaction to ensure that uncertainty and risks inherent in business situations are adequately considered". Textbooks commonly present conservatism as the choice of an accounting treatment that least likely overstates assets and income when selecting among two or more reporting alternatives [24]. However such definition are difficult to interpret; the cumulative effect of alternative accounting treatments for a given transaction over a full business cycle should be the same, so conservatism in one period may lead to non-conservative results in some subsequent period. Watts defines conservatism as differential verifiability required for the recognition of profits versus losses. Beaver and Ryan define conservatism as a persistent downward bias in book value relative to market value. In the absence of one unifying definition, conservatism has typically been measured many ways by examining properties of either balance sheet or income statement information such asasymmetric timeliness in earnings, downward bias in book values relative to market values and downward bias in earnings [25].

International Accounting standard board framework for the preparation and presentation of financial statement (IASB framework) says in paragraph 26 that information is relevant "when it influences the economic decisions of users by helping them evaluate past, present or future events or confirming, or correcting, their past evaluations", Financial Accounting Standard Board (FASB) concepts statement No. 2, Qualitative Characteristics of Accounting Information (FASB concepts statement 2) says in paragraph 47 that, to be relevant, "accounting information must be capable of making a difference in a decision by helping users to form predictions about the outcomes of past, present, and future events or to confirm or correct expectations." These definitions are quite similar.

The italics added here emphasize the only real difference; whether information must influence decisions or only be capable of influencing decisions. IASB framework paragraph 29 and 30 stated that the relevance of information is affected by its nature and materiality, noting that materiality provides a threshold or cut-off point rather than being primary qualitative characteristics. FASB concepts statement 2 also characterizes materiality as a threshold but discusses materiality separately from relevance. IASB framework paragraph 43 , timeliness is cited as a necessary constraint lest information lose its relevance. In FASB concepts statement 2, paragraph 56, timeliness is considered "an ancillary aspect of relevance. If information is not available at the time it is required it has no value for future action, it lacks relevance and is of little or no use.

One reason for conservative accounting is the potential for error in the measurement, and correspondingly a lack of reliability. Conservative accounting policies might result to accounting numbers that are likely to be more reliable since conservatism favour less subjective measures and less estimation. The usefulness of information for decisions (i.e. relevance) depends on the reliability of such information; hence relevance could actually increase with conservatism. Given these arguments in opposite directions, it is an empirical question whether conservatism and value relevance behave as complements or substitutes.

\section{Conclusion}

The value relevance of accounting information has been criticized by the stock market researchers in accounting. A number of studies have created the impression that accounting numbers have lost their value relevance. The extant literature on value relevance has consistently found that the value relevance of earnings has been decreasing over time. Literature has also found that the value relevance of book values has been increasing; however results are mixed. Conservatism has survived in accounting for many years. Conservatism simply states that we should "anticipate no profit but anticipate all losses". Conservatism imposes a high threshold of verifiability and provides information that is useful for many purposes including contracting. Conservatism accounting requires verifiability that minimizes the potential for errors in measurement, and correspondingly increases the reliability of the resulting information. If unverified information is sufficiently unreliable, the relevance of that information may well be diminished; hence relevance might be positively associated with conservatism.

\section{Recommendation}

The direction of the relationship between value relevance and conservatism is unclear. Regulators commonly describe accounting treatments as "trade-offs" between relevance and reliability; furthermore when the regulators are criticized, the critiques commonly portray regulations as having erred in the favour of one side at the expense of the other. The presumption behind trade-off is that relevance decreases in conservatism. The recommendation therefore is that the financial reporting council and other allied bodies should ensure clarity and provide rules with probably less discretionary tendencies for management to manipulate. The overall aim is to improve credibility of financial information.

\section{References}

1. Holthausen R, Watts R (2002) The Relevance of the Value Relevance Literature for Financial Accounting Standard Setting. Journal of Accounting and Economics 31: 3-75

2. Penman S, Zhang $X$ (2002) Accounting Conservatism, the Quality of Earnings and Stock Returns. The Accounting Review77: 237-264.

3. Hayley PM, Palepu KG (2001) Information Asymmetry, Corporate Disclosure and the Capital Markets: A Review of the Empirical Disclosure Literature. Journal of Accounting and Economics 31: 405-440.

4. Kothari SP (2001) Capital Market Research in Accounting. Journal of Accounting and Economics 31: 105-231.

5. Francis J, Schipper K (1999) How Financial Statements lost their Relevance. Journal of Accounting Research 37: 319-353.

6. Ely K, Waymire GB (1999) Accounting Standard-Setting Organizations and Earnings Relevance: Longitudinal Evidence from NYSE Common Stocks.

7. Dontoh A, RadhakrishanS, Ronen J (2004) The Declining Value Relevance of Accounting Information and Non-Information-based Trading: An Empirical Analysis. Contemporary Accounting Research.

8. Ball R, Shivakumar L (2008) Earnings Quality in UKPrivate Firms: Comparative less recognition timeliness, J Accoun Econ 39: 83-128.

9. Hung M (2001) Accounting Standards and Value Relevance of Financial Statements: An International Analysis J Accoun Econ 30: 401-420.

10. Ali A, L Hwang (2000) Country Specific Factors Related to Financial Reporting and the Value Relevance of Accounting Data.Journal of Accounting Research 38: 1-22.

11. Chen CJP, Chen S, Su X (2001) Accounting Information Value Relevance in the Emerging Chinese Stock Market. Journal of International Accounting Auditing and Taxation10: 1-22.

12. Brimble M, Hodgson A (2003) On the Inter-temporal Value Relevance 
Citation: Felix UO, Rebecca UI (2015) Theory of Conservatism and Value Relevance of Accounting Information. J Account Mark 4: 121. doi: 10.4172/2168-9601.1000121

of Conventional Financial Accounting in Australia. Accounting and Finance47:599-622.

13. Lev B, D Nissim (2004) Taxable Income as an Indicator of Earnings Quality. The Accounting Review 1039-1074.

14. Feltham G, Ohlson J (1995) Valuation and Clean surplus Accounting for Operating and Financial Activities. Contemporary Accounting Research 11: 689-731.

15. Basu S (1997) The Conservatism Principle and the Asymmetric Timeliness of Earnings. Journal of Accounting and Economics 24: 3-37.

16. Beaver WH, Ryan SG (2000) Biases and Lags in Book Value and their Effects on the Ability of the book-to-market Ratio to Predict Book Return on Equity. Journal of Accounting Research 38: 127-148.

17. Givolyn D, Hayn C (2000) The Changing time-series Properties of Earnings, Cash Flows and Accruals: Has Financial reporting become more conservative? Journal of Accounting and Economics. 29: 287-320.

18. Barth, Mary E, Beaver WH, Wayne R, Landman (2001) The Relevance of the Value Relevance Literature for Financial Accounting Standard setting: another view. 31: 77-104
19. Hellstrom K (2005) The Value Relevance of Financial Accounting Information in a Traditional Economy: The case of the Czech Republic. Working Papers Series in Business Administration.

20. Gjerde Q, Knivsfia F, Saettem F (2011) The Value Relevance of Financial Reporting in Norway 1965-2004. Scandinavian Journal of Management 27: 113-128.

21. Neelan MH (2007) Focus on Finance and Accounting Research. Nova Science Publishers, New York.

22. Easton PD, Harris TS (1991) Earnings as an Explanatory Variable for Returns. Journal of Accounting Research 29: 19-36.

23. Efficient Market Hypothesis-EMH (2009) Investopedia.

24. Kieso D, Weygandt J, Warfield T (2004) Intermediate Accounting. Wiley, New York.

25. Beaver WH (2002) Perspective of Recent Capital market Research. The Accounting Review 77: 187-215. 